\title{
The effect of sodium butyrate on calf growth and serum level of $\beta$-hydroxybutyric acid
}

\author{
K. Ślusarczyk ${ }^{1}$, J.A. Strzetelski ${ }^{2,3}$ and I. Furgal-Dierżuk ${ }^{2}$ \\ National Research Institute of Animal Production, \\ ${ }^{1}$ Central Laboratory, \\ ${ }^{2}$ Department of Animal Nutrition and Feed Science \\ 32-083 Balice, Poland
}

(Received 7 October 2009; revised version 31 March 2010; accepted 16 August 2010)

\begin{abstract}
The experiment was carried out on 40 Polish Black-and-White HF bull calves $(52-87 \%$ of HF blood) aged from 9 and 12 days at the beginning of the experiment to 90 days at its end. From the beginning of the trial the calves were offered restricted liquid feed to 56 days of age and concentrates ad libitum according to IZ-PIB-INRA recommendations. The concentrates were without sodium butyrate (control group, C), or with 1\% Na-butyrate (group B1), 3\% Na-butyrate (group B3) and 0.3\% Na-butyrate (group B0.3), and included meadow hay from $0.10 \mathrm{~kg}$ /day during the liquid feeding period to $0.20 \mathrm{~kg}$ /day after weaning at 57 days of age. Na-butyrate at $3 \%$ in the diet reduced feed intake and had a beneficial effect on calf growth and nutrient utilization. The dietary level of Na-butyrate did not cause significant changes in serum $\beta$-hydroxybutyric acid concentration of the calves.
\end{abstract}

KEY WORDS: calves, sodium butyrate, $\beta$-hydroxybutyric acid

\section{INTRODUCTION}

Early transition from simple gastric digestion to functional ruminal digestion in dairy calves is essential for their health and growth (Khan et al., 2007). This transition involves a number of anatomical and physiological changes in the forestomach, especially in the rumen. These processes affect rumen development in pre-weaned calves and are essentially caused by nutrients supplied by solid feed (cereal grains and hay). Forage consumption promotes muscular development of

\footnotetext{
${ }^{3}$ Corresponding autor: e-mail: jstrzet@izoo.krakow.pl
} 
the rumen and stimulates rumination and flow of saliva into the rumen (Hodgson, 1971; Hamada et al., 1976). Forage digestion by microorganisms does not provide sufficient concentrations of rumen volatile fatty acids (VFA), especially butyrate and, to a lesser degree, propionate, required for papillae development (Coverdale et al., 2004). The necessary butyrate concentration required to stimulate rumen mucosa (papillae) development is provided by concentrate fermentation, but on the other hand, large amounts of ground concentrate increase keratinization of the ruminal wall (Mc Gavin and Morrill, 1976), which reduces VFA absorption (Nocek et al., 1980; Greenwood et al., 1997), and rumen papillae branch to compensate for the loss in metabolically active tissue (Greenwood et al., 1997; Beharka et al., 1998).

Rumen mucosa development is stimulated by concentrates with a significant potential for fermentation to butyric and propionic acids (Greenwood et al., 1997; Beharka et al., 1998; Baldwin et al., 2004). This effect is most likely associated with the rate at which these acids are metabolized by mucosal cells. Around $50 \%$ of propionic acid is metabolized during absorption and over $90 \%$ of butyric acid is oxidized to ketone bodies (Britton and Krehbill, 1993). Poor mucosa development was observed in animals fed for a longer time (up to 12 weeks) with milk or milk replacers (Stobo et al., 1966). The addition of aqueous VFA solutions, in particular butyric and propionic acids or their salts, to the rumen of milk-fed calves stimulated the development of rumen mucosa (Lane and Jesse, 1997). Butyric acid salts (Na-butyrate or Ca-butyrate) are often used instead of the acid in animal nutrition because the salts are more stable and less odorous. Supplementing liquid feed with Na-butyrate enhanced the growth performance of young calves and villus size of the intestinal tract and modified the activity of digestive enzymes (Guilloteau et al., 2009). Lane et al. (2002) showed that the development of the ketogenic capacity of ruminal epithelium occurs as the animals ages and that the genes encoding the enzymes controlling ketogenesis are expressed independently of intraruminal VFA concentrations. There is no conclusive evidence, however, whether sodium butyrate can affect these processes.

The aim of the experiment was to determine if supplementing different amounts of sodium butyrate to concentrates for calves has differing effects on the serum levels of $\beta$-hydroxybutyric acid (an indicator of ketogenesis) and calf rearing performance.

\section{MATERIAL AND METHODS}

\section{Animals, feeding and management}

The experiment was carried out on 40 Polish Black-and-White HF bull calves 
(52-87\% of HF blood) aged from 9 to 12 days at the beginning, to 90 days at the end of the experiment. Calves were assigned to four groups of 10 animals each according to day of birth and liveweight. The calves were kept in individual cages $(1.8 \times 0.9 \mathrm{~m})$ on a perforated wooden floor without litter.

Before the experiment the calves received only colostrum and milk. From the beginning of the trial all of the calves were offered liquid feed (to 56 days of age) and concentrates ad libitum (Table 1) that contained no sodium butyrate (control group, C), 1\% Na-butyrate (group B1), 3\% Na-butyrate (group B3), or 0.3\% Nabutyrate (group B0.3). Meadow hay was fed from $0.10 \mathrm{~kg} /$ day during the liquid feeding period to $0.20 \mathrm{~kg}$ /day after weaning.

Table 1. Composition of concentrate, $\%$

\begin{tabular}{|c|c|c|c|c|}
\hline \multirow{2}{*}{ Feed component } & \multicolumn{4}{|c|}{ Group } \\
\hline & $\mathrm{C}$ & B1 & B3 & B0.3 \\
\hline Wheat, ground & 30.0 & 30.0 & 30.0 & 30.0 \\
\hline Maize, ground & 30.0 & 29.0 & 27.0 & 29.7 \\
\hline Oat, rolled & 15.0 & 15.0 & 15.0 & 15.0 \\
\hline Soyabean oilmeal & 20.0 & 20.0 & 20.0 & 20.0 \\
\hline Na-butyrate & - & 1.0 & 3.0 & 0.3 \\
\hline Premix ${ }^{1}$ & 3.0 & 3.0 & 3.0 & 3.0 \\
\hline Limestone & 1.0 & 1.0 & 1.0 & 1.0 \\
\hline $\mathrm{CaHPO}_{4}$ & 1.0 & 1.0 & 1.0 & 1.0 \\
\hline
\end{tabular}

${ }^{1}$ Kalber Gold Mineral (Sano firm), in $1 \mathrm{~kg}$ : g: P 40, Ca 20, Mg 25, Na 80; mg: Cu 1000, Zn 12000, Mn 4000, vit. E 3000; IU: vit. A 1000000, vit. D 100000

Liquid feed was prepared from milk replacer powder that contained, according to the manufacturer's specification, milk protein concentrate, whey, animal fat, coconut oil and Soycomil. The concentration of solid milk replacer in liquid feed was $140 \mathrm{~g} / \mathrm{l}$ liquid. The calves were fed milk replacer solution according to IZ-PIB-INRA (2009) recommendations. The protein and energy value of feeds, and the proportion of ingredients in concentrates were formulated according to these standards using INRAtion and PrévAlim version 3.x (2005) software based on our own chemical analysis of feeds and using coefficients of rumen protein degradability (deg) and intestinal digestibility (dsi) for concentrate components and hay. For milk replacer, the $\operatorname{deg}=0.01$ (due to the function of the reticular groove) and dsi $=0.95$ (IZ-PIBINRA, 2009) values were assumed.

The liveweight of calves was monitored over two successive days at the beginning of the experiment, at weaning, and at the end of the experiment.

Starting from 7 days of age, blood samples were taken from the jugular vein into 9-ml tubes with clot activator (Vacuette) and at 14, 42 and 90 days of age ( $4 \mathrm{~h}$ after the morning feeding) and centrifuged; the obtained serum was refrigerated at $-18^{\circ} \mathrm{C}$. 
The animals were fed individually. Feed intake was monitored daily by weighing feed refusals, and representative samples were analysed at one-month intervals at the Central Laboratory of the National Research Institute of Animal Production. Liquid feed was provided from plastic buckets with nipples; water was offered ad libitum.

\section{Chemical and statistical analysis}

Proximate chemical analysis of feeds and refusals was performed according to AOAC (1990). $\beta$-hydroxybutyric acid (BHBA) was determined by a kinetic enzymatic reaction using a Cobas-Bio analyser (Roche) and a high-sensitivity reagent kit (RANDOX). Glucose was determined by dry chemistry using the glucose oxidase method with a VITROS 950 analyzer (Ortho-Clinical Diagnostic) as described in the Test Methodology Manual (1996), the instructions for use of this analyzer.

\section{Calculations and statistical analysis}

Liveweight, daily weight gains and serum concentration of BHBA and glucose in respective periods of the experiment were analysed statistically using the MIXED procedure (SAS, 2001) of one-way analysis of variance with repeated measures based on the following model:

$$
\mathrm{Y}_{\mathrm{ijk}}=\mu+\alpha_{\mathrm{i}}+\mathrm{d}_{\mathrm{ij}}+\tau_{\mathrm{k}}+(\alpha \tau)_{\mathrm{ik}}+\mathrm{e}_{\mathrm{ijk}},
$$

where: $Y_{i j k}$ - dependent variable, $\mu$ - overall mean, $\alpha_{i}$ - fixed effect of group, $\mathrm{d}_{\mathrm{ij}}$ - random effect of $\mathrm{j}$ animal in $\mathrm{i}$ group, $\tau_{\mathrm{k}}$ - fixed effect of time $\mathrm{k},(\alpha \tau)_{\mathrm{ik}}$ - effect of the fixed interaction between $\mathrm{i}$ group and $\mathrm{k}$ age, $\mathrm{e}_{\mathrm{ijk}}$ - random error $\mathrm{i}=\mathrm{C}, \mathrm{B}-1, \mathrm{~B}=-3$ or B- $0.3 \mathrm{k}-$ days of age $(7,14,42,90)$.

Statistical analysis of daily feed and nutrient intakes during particular periods and feed and nutrient conversion efficiency for all periods of the experiment was performed using one-way analysis of variance according to the GLM procedure of SAS (2002) by estimating the significance of differences between groups with Duncan's multiple range test. Differences were considered significant at $\mathrm{P} \leq 0.05$ and tendencies at $\mathrm{P}<0.15$. 


\section{RESULTS}

The chemical composition and nutritive value of the feeds are given in Table 2 . The energy and protein levels were similar in all concentrates. At different periods of the experiment, compared with groups $\mathrm{B} 1$ and $\mathrm{B} 0.3$, calves from groups $\mathrm{C}$ and $\mathrm{B} 3$ were characterized by a tendency towards lower $(\mathrm{P}<0.1)$ or significantly lower $(\mathrm{P}=0.05$ or $\mathrm{P}<0.01$ ) feed and nutrient intakes (Table 3 ), except the intake of milk replacer and PDIN before weaning and the intake of hay for the entire experimental period $(\mathrm{P}>0.05)$.

Table 2. Chemical composition and nutritive value of the feeds

\begin{tabular}{|c|c|c|c|c|c|c|c|c|}
\hline Components & $\begin{array}{c}\text { Dry } \\
\text { matter } \\
\%\end{array}$ & $\begin{array}{c}\text { Crude } \\
\text { protein } \\
\% \\
\end{array}$ & $\begin{array}{c}\text { Ether } \\
\text { extract } \\
\%\end{array}$ & $\begin{array}{c}\text { Crude } \\
\text { fibre } \\
\%\end{array}$ & $\begin{array}{c}\text { Ash } \\
\%\end{array}$ & $\begin{array}{l}\text { PDIN } \\
\mathrm{g} \cdot \mathrm{kg}^{-1}\end{array}$ & $\begin{array}{l}\text { PDIE } \\
\mathrm{g} \cdot \mathrm{kg}^{-1}\end{array}$ & $\begin{array}{l}\text { UFL } \\
\text { in } 1 \mathrm{~kg}\end{array}$ \\
\hline Wheat, ground & 87.85 & 13.22 & 2.17 & 2.66 & 1.60 & 88 & 93 & 1.02 \\
\hline Maize, ground & 89.61 & 9.34 & 3.82 & 2.03 & 1.30 & 73 & 91 & 1.09 \\
\hline Oat, rolled & 87.93 & 10.55 & 2.44 & 9.34 & 2.61 & 65 & 69 & 0.80 \\
\hline Milk replacer, powder ${ }^{1}$ & 91.77 & 21.40 & 12.00 & & 6.2 & 211 & - & 1.33 \\
\hline Na-butyrate ${ }^{2}$ & 99 & & & & & & & 1.74 \\
\hline Meadow hay & 83.75 & 8,34 & 2.36 & 28.96 & 4.47 & 18 & 43 & 0.65 \\
\hline \multicolumn{9}{|l|}{ Concentrates for group } \\
\hline $\mathrm{C}-0$ & 88.70 & 17.50 & 2.63 & 3.50 & 2.58 & 125 & 112 & 0.97 \\
\hline B-1 & 88.7 & 17.40 & 2.60 & 3.40 & 2.52 & 125 & 111 & 0.98 \\
\hline B-3 & 88.7 & 17.20 & 2.52 & 3.40 & 2.55 & 123 & 109 & 0.99 \\
\hline \multirow[t]{2}{*}{ B-0.3 } & 88.7 & 17.5 & 2.57 & 3.50 & 2.62 & 125 & 112 & 0.97 \\
\hline & & & 2.90 & 3.90 & 2.95 & 141 & 126 & 1.09 \\
\hline
\end{tabular}

${ }^{1}$ PDIN as PDI corresponds to digested crude protein; ${ }^{2}$ net energy value (NEL) expressed as UFL was evaluated taking into account gross energy (GE) in calorimetric bomb estimated $\left(6026 \mathrm{kcal} \cdot 1 \mathrm{~kg}^{-1}\right)$ and GE of animal fat utilization for NEL (49.6\%) and value of 1 UFL according to IZ PIB-INRA standards (2009)

The age of calves (Table 4) had a significant effect on liveweight and daily weight gains $(\mathrm{P}<0.01)$, with no significant differences among the groups, although calves receiving Na-butyrate showed a tendency towards higher liveweight and higher weight gains $(\mathrm{P}=0.087$ and $\mathrm{P}=0.13)$. Compared with the control group $(\mathrm{C})$, calves from all $\mathrm{B}$ groups had significantly higher liveweight at 57 and 90 days of age. In all periods of the experiment, calves receiving feeds with Na-butyrate (groups $\mathrm{B}$ ) had higher daily weight gains $(\mathrm{P}<0.05$ and $\mathrm{P}=0.053)$ compared with those from group $\mathrm{C}$. Compared with the other groups, calves receiving concentrates with 3\% Na-butyrate concentrate utilized nutrients $(\mathrm{P}=0.02)$ better and showed slightly better nutrient conversion efficiency, but differences in relation to group $\mathrm{C}$ were not significant (Table 5). 
Table 3. Daily intake of feeds and nutrients during different periods of the experiment

\begin{tabular}{|c|c|c|c|c|c|c|}
\hline Items & C & B-1 & B-3 & B- 0.3 & $\mathrm{P}$ & SE \\
\hline \multicolumn{7}{|l|}{ Before weaning } \\
\hline milk replacer, powder, $\mathrm{kg} \cdot \mathrm{day}^{-1}$ & 0.97 & 0.97 & 0.97 & 0.97 & 0.64 & 0.001 \\
\hline concentrate, $\mathrm{kg}^{-\mathrm{day}^{-1}}$ & 0.61 & 0.83 & 0.73 & 0.86 & 0.07 & 0.04 \\
\hline hay, $\mathrm{kg} \cdot \mathrm{day}^{-1}$ & 0.05 & 0.07 & 0.06 & 0.06 & 0.08 & 0.002 \\
\hline dry matter, ${\mathrm{kg} \cdot \mathrm{day}^{-1}}^{-1}$ & 1.47 & 1.68 & 1.58 & 1.70 & 0.052 & 0.03 \\
\hline crude protein, $g \cdot d^{-1}$ & 317.7 & 358.5 & 339.4 & 361.8 & 0.058 & 6.48 \\
\hline PDIN, g.day ${ }^{-1}$ & 281.0 & 309.6 & 294.7 & 312.2 & 0.20 & 5.09 \\
\hline PDIE, g.day ${ }^{-1}$ & 274.4 & 300.5 & 288.1 & 302.6 & 0.057 & 4.13 \\
\hline UFL, day ${ }^{-1}$ & 1.91 & 2.5 & 2.04 & 2.15 & 0.052 & 0.04 \\
\hline \multicolumn{7}{|l|}{ After weaning } \\
\hline concentrate, $\mathrm{kg} \cdot \mathrm{day}^{-1}$ & $2.61^{\mathrm{a}}$ & $3.23^{\mathrm{b}}$ & $2.77^{\mathrm{ac}}$ & $2.99^{\mathrm{bc}}$ & 0.004 & 0.07 \\
\hline hay, $\mathrm{kg} \cdot \mathrm{day}^{-1}$ & 0.20 & 0.19 & 0.20 & 0.19 & 0.055 & 0.003 \\
\hline dry matter, $\mathrm{kg} \cdot \mathrm{day}^{-1}$ & $2.48^{\mathrm{a}}$ & $3.02^{\mathrm{b}}$ & $2.62^{\mathrm{ac}}$ & $2.81^{\mathrm{bc}}$ & 0.05 & 0.06 \\
\hline crude protein, $g \cdot$ day $^{-1}$ & $473.5^{\mathrm{a}}$ & $577.6^{\mathrm{b}}$ & $492.9^{\mathrm{ac}}$ & $539.4^{\mathrm{bc}}$ & 0.004 & 11.85 \\
\hline PDIN, g.day ${ }^{-1}$ & $329.7^{\mathrm{a}}$ & $406.8^{\mathrm{b}}$ & $344.2^{\mathrm{ac}}$ & $377.2^{\mathrm{bc}}$ & 0.003 & 8.57 \\
\hline PDIE, g·day ${ }^{-1}$ & $300.9^{\mathrm{a}}$ & $366.5^{\mathrm{b}}$ & $310.4^{\mathrm{ac}}$ & $343.2^{\mathrm{bc}}$ & 0.004 & 7.60 \\
\hline UFL, day $^{-1}$ & $2.66^{\mathrm{a}}$ & $3.29^{\mathrm{b}}$ & $2.87^{\mathrm{ac}}$ & $3.03^{\mathrm{bc}}$ & 0.004 & 0.07 \\
\hline \multicolumn{7}{|l|}{ Whole experimental period } \\
\hline concentrate, $\mathrm{kg} \cdot \mathrm{day}^{-1}$ & $1.48^{\mathrm{a}}$ & $1.87^{\mathrm{b}}$ & $1.64^{\mathrm{ac}}$ & $1.79^{\mathrm{bc}}$ & 0.008 & 0.05 \\
\hline hay, $\mathrm{kg} \cdot \mathrm{day}^{-1}$ & 0.12 & 0.12 & 0.12 & 0.12 & 0.81 & 0.002 \\
\hline dry matter, $\mathrm{kg} \cdot \mathrm{day}^{-1}$ & $1.91^{\mathrm{a}}$ & $2.27^{\mathrm{b}}$ & $2.05^{\mathrm{ac}}$ & $2.19^{\mathrm{bc}}$ & 0.006 & 0.04 \\
\hline crude protein, $g \cdot$ day $^{-1}$ & $386.7^{\mathrm{a}}$ & $453.2^{\mathrm{b}}$ & $407.6^{\mathrm{ac}}$ & $440.8^{\mathrm{bc}}$ & 0.006 & 7.97 \\
\hline PDIN, g.day ${ }^{-1}$ & $302.1^{\mathrm{a}}$ & $351.9^{\mathrm{b}}$ & $317.9^{\mathrm{ac}}$ & $340.8^{\mathrm{bc}}$ & 0.005 & 5.72 \\
\hline PDIE, g.day ${ }^{-1}$ & $287.0^{\mathrm{a}}$ & $328.8^{\mathrm{b}}$ & $297.9^{\mathrm{ac}}$ & $320.5^{\mathrm{bc}}$ & 0.005 & 5.07 \\
\hline UFL, day $^{-1}$ & $2.24^{\mathrm{a}}$ & $2.64^{\mathrm{b}}$ & $2.42^{\mathrm{ac}}$ & $2.54^{\mathrm{bc}}$ & 0.005 & 0.04 \\
\hline
\end{tabular}

Table 4. Liveweight and daily liveweight gains

\begin{tabular}{|c|c|c|c|c|c|c|c|c|}
\hline \multirow{2}{*}{ Liveweight } & \multicolumn{4}{|c|}{ Group } & \multicolumn{3}{|c|}{$\mathrm{P}$} & \multirow{2}{*}{$\begin{array}{l}\text { Contrast } \\
\text { C vs B }\end{array}$} \\
\hline & $\mathrm{C}$ & B1 & B3 & B0.3 & group & age & GxA & \\
\hline Initial, kg & 48.3 & 50.1 & 50.4 & 49.1 & 0.087 & $<0.01$ & 0.26 & 0.47 \\
\hline At weaning, 57 days of age, $\mathrm{kg}$ & 66.4 & 72.9 & 72.2 & 71.4 & & & & 0.03 \\
\hline Final, $\mathrm{kg}$ & 98.4 & 107.8 & 108.1 & 103.5 & & & & 0.02 \\
\hline \multicolumn{9}{|l|}{ Daily gains, $\mathrm{g} \cdot \mathrm{day}^{-1}$} \\
\hline $\begin{array}{l}\text { from beginning of experiment } \\
\text { to weaning }\end{array}$ & 390.1 & 488.2 & 477.0 & 484.8 & 0.13 & $<0.01$ & 0.73 & 0.03 \\
\hline $\begin{array}{l}\text { from weaning to the end } \\
\text { of experiment }{ }^{1}\end{array}$ & 914.3 & 997.1 & 1025.7 & 917.1 & & & & 0.053 \\
\hline $\begin{array}{l}\text { from beginning to the end } \\
\text { of experiment }{ }^{1}\end{array}$ & 617.1 & 708.8 & 717.7 & 680.0 & & & & 0.04 \\
\hline
\end{tabular}


Table 5. Concentrates and nutrient conversion efficiency, per kg gain

\begin{tabular}{lcccccc}
\hline Item & $\mathrm{C}$ & $\mathrm{B}-1$ & $\mathrm{~B}-3$ & $\mathrm{~B}-0.3$ & $\mathrm{SE}$ & $\mathrm{P}$ \\
\hline Concentrates, $\mathrm{kg}$ & $2.40^{\mathrm{ab}}$ & $2.64^{\mathrm{a}}$ & $2.28^{\mathrm{b}}$ & $2.67^{\mathrm{a}}$ & 0.31 & 0.02 \\
Dry matter, kg & 3.09 & 3.20 & 2.87 & 3.22 & 0.07 & 0.18 \\
Crude protein, kg & 624.4 & 639.4 & 567.0 & 646.8 & 14.59 & 0.13 \\
PDI, g & 465.1 & 463.9 & 415.1 & 471.3 & 9.87 & 0.12 \\
UFL & 3.63 & 3.72 & 3.37 & 3.73 & 0.08 & 0.26 \\
\hline
\end{tabular}

SE - standard error for the population; ${ }^{\mathrm{a}, \mathrm{b}, \mathrm{c}}-\mathrm{P} \leq 0.05$

The serum level of the analysed metabolite varied according to calves' age $(\mathrm{P}<0.01)$, with no statistically significant differences between individual groups or between group $\mathrm{C}$ and all $\mathrm{B}$ groups (Table 6). As the calves grew, the concentration

Table 6 . Concentration of $\beta$-hydroxybutyric acid (BHBA) and serum glucose, $\mathrm{mmol} \cdot \mathrm{l}^{-1}$

\begin{tabular}{|c|c|c|c|c|c|c|c|c|}
\hline \multirow{2}{*}{ Age, days } & \multicolumn{4}{|c|}{ Group } & \multicolumn{3}{|c|}{$\mathrm{P}$} & \multirow{2}{*}{$\begin{array}{l}\text { Contrast } \\
\text { C vs B }\end{array}$} \\
\hline & $\mathrm{C}$ & B1 & B3 & B0.3 & group & age & $\mathrm{G} \times \mathrm{A}$ & \\
\hline BHBA concentration & & & & & 0.21 & $<0.01$ & 0.81 & \\
\hline 7 & 0.07 & 0.06 & 0.06 & 0.06 & & & & 0.50 \\
\hline 14 & 0.19 & 0.21 & 0.22 & 0.18 & & & & 0.60 \\
\hline 42 & 0.21 & 0.22 & 0.23 & & & & & 0.93 \\
\hline 90 & 0.30 & 0.31 & 0.35 & 0,19 & & & & 0.23 \\
\hline Glucose concentration & & & & & 0.91 & $<0.01$ & 0.99 & \\
\hline 7 & 3.65 & 3.78 & 3.77 & 3.60 & & & & 0.82 \\
\hline 14 & 2.20 & 2.27 & 2.48 & 2.18 & & & & 0.70 \\
\hline 42 & 2.40 & 2.50 & 2.55 & 2.73 & & & & 0.50 \\
\hline 90 & 3.80 & 3.72 & 3.70 & 3.61 & & & & 0.67 \\
\hline
\end{tabular}

of $\beta$-hydroxybutyric acid was found to increase in all experimental groups. Before the start of the experiment when the colostrum and milk feeding periods were over ( 7 days of age), serum levels of BHBA were low $\left(0.06-0.07 \mathrm{mmol} \cdot \mathrm{l}^{-1}\right)$ but gradually increased four-fold (group C), five-fold (groups B1 and B0.3), and sixfold (group B3) at 90 days of age $(\mathrm{P}<0.01)$. The highest numerical values for serum glucose concentrations were found at 7 and 90 days, and the lowest, at 14 days of age.

There was no significant interaction between group and age for liveweight, daily weight gains, and serum BHBA and glucose concentration.

\section{DISCUSSION}

These results indicate that Na-butyrate given together with concentrates under the conditions of this study stimulated feed intake and growth of the calves. Compared with groups $\mathrm{B} 1$ and $\mathrm{B} 0.3$, however, a $3 \%$ proportion of Na-butyrate 
in concentrate caused daily feed intake to decrease by about $10 \%( \pm 2$ percentage units). This Na-butyrate concentration probably increased the odour offensiveness of the diets compared with the groups of calves fed diets with 1.0 or $0.3 \% \mathrm{Na}$ butyrate. Nonetheless, calves from group B3 grew slightly more rapidly and were more efficient in feed conversion. It can be assumed that this was due to the higher intake of Na-butyrate and thus to the better development of rumen mucosa in terms of rumen absorption surface area and rumen cell metabolism. Although calves from group B1, and particularly those from group B0.3, had greater feed intake, they grew less and utilized feed less efficiently compared with calves from group B3.

Lane and Jesse (1997) observed rumen papillae to elongate in milk-fed lambs receiving short-chain fatty acids. Not all acids stimulated epithelial growth to the same extent, however. The greatest effect was shown by butyric acid, followed by propionic and acetic acids, which is most probably due to different rates of mucosa cell apoptosis under the influence of these acids (Mentschel et al., 2001) or different rates of acid metabolism in mucosa cells. After being absorbed by ruminal epithelium, VFA are converted into ketoacids that provide energy during synthesis of different substrates in the liver (Beharka et al., 1988). Because ruminal mucosa cells metabolize about $90 \%$ of butyric acid, it can be assumed that changes in serum concentration of BHBA will be a good indicator of metabolic changes in these cells (Baldwin and Jesse, 1992).

Determination of the serum $\beta$-hydroxybutyric acid concentration in calves is regarded as a noninvasive indicator of rumen development, but the results are not always consistent. Some authors observed the serum concentration of $\beta$-hydroxybutyric acid to increase with age and feed intake (Quigley et al., 1992). Quigley and Bernard (1992) report that between days 28 and 42 of age, the blood concentration of BHBA ranges from 0.22 to $0.62 \mathrm{mM}$. Similar findings were obtained in the present study for all groups of calves at 42 days of age. This relationship was not observed by Coverdale et al. (2004). Lane et al. (2000) found BHBA production to increase in 42-day-old lambs receiving milk alone or milk and concentrate. These observations suggest that the presence of VFA may not be the only factor inducing the development of ketogenesis, which may occur through ontogenesis or the action of other factors (Lane et al., 2000). This is perhaps the reason why no differences in serum BHBA concentrations were found between the groups, despite different proportions of Na-butyrate in the calf diets. It is likely, however, that Na-butyrate could pass into the small intestine and have a positive effect on the development of intestinal mucosa and intestinal enzyme activity. Guilloteau et al. (2009) believe that Na-butyrate is a specific stimulant of calf growth and is largely active in the intestines, where it has a favourable effect on villus length, crypt depth, mitotic index (Kotunia et al., 2004) and enzyme 
activity. Böcker et al. (2003) reported a favourable effect of Na-butyrate on the expression of genes regulating the development of intestinal mucosa.

Changes in serum glucose concentrations from 7 to 14 and 42 days of age indicate that glucose oxidation decreased in ruminal mucosa cells, with increases in the use (by mitochondria of mucosal cells) of VFA from microbiological fermentation for ketone body synthesis, and of Na-butyrate from feed. Although no significant differences were found among the groups in serum glucose concentrations, its numerical values in the B groups were slightly higher at 42 days compared with the control group. The glucose concentration at 90 days, which was similar to that at 7 days, suggests that gluconeogenesis intensified during this period.

\section{CONCLUSIONS}

Adding 1-3\% Na-butyrate to calf diets could result in better rearing performance, since adding 3\% Na-butyrate reduced feed intake while having a beneficial effect on calf growth and nutrient utilization. The dietary level of Na-butyrate did not significantly change serum $\beta$-hydroxybutyric acid concentration in the calves.

\section{REFERENCES}

AOAC, 1990. Association of Official Analytical Chemists, Official Methods of Analysis. 15 ${ }^{\text {th }}$ Edition. Washington, DC

Baldwin R.L.VI, Jesse B.W., 1992. Developmental changes in glucose and butyrate metabolism by isolated sheep ruminal cells. J. Nutr. 122, 1149-1153

Baldwin R.L., McLeod K.R.VI, Heitman R.N., 2004. Rumen development, intestinal growth and hepatic metabolism in the pre- and post-weaning ruminant. J. Dairy Sci. 87, Suppl. E, E55E65

Beharka A.A., Nagraja T.G., Morrill J.L., Kennedy G.A., Klemm R.D., 1998. Effects of form of the diet on anatomical, microbial, and fermentative development of the rumen of neonatal calves. J. Dairy Sci. 81, 1946-1955

Böcker U., Nebe T., Herweck F., Holt L., Panjas A., Jobin C., Rossol S., Sartor R.B., Singer M.V., 2003. Butyrate modulates intestinal epithelial cell-mediated neutrophil migration. Clin. Exp. Immunol. 131, 53-60

Britton R., Krehbill C., 1993. Nutrient metabolism by gut tissue. J. Dairy Sci. 76, 2125-2131

Coverdale J.A., Tyler H.D., Quigley J.D. III, Brumm J.A., 2004. Effect of various levels of forage and form of diet on rumen development and growth in calves. J. Dairy Sci. 87, 2554-2562

Greenwood R.H., Morrill J.L., Titgemeyer E.C., Kennedy G.A., 1997. A new method of measuring diet abrasion and its effect on the development of the forestomach. J. Dairy Sci. 80, 25342541

Guilloteau P., Zabielski R., David J.C., Blum J.W., Morisset J. A., Biernat M., Woliński J., Laubitz D., Hamon Y., 2009. Sodium-butyrate as a growth promoter in milk replacer formula for young calves. J. Dairy Sci. 92, 1038-1049 
Hamada T.S., Maeda S., Kameoka K., 1976. Factors influencing growth of rumen, liver, and other organs in kids weaned from milk replacers to solid foods. J. Dairy Sci. 59, 1110-1118

Hodgson J., 1971. The development of solid food intake in calves. 1. The effect of previous experience of solid food, and the physical form of the diet, on the development of food intake after weaning. Anim. Prod. 13, 15-24

IZ PIB-INRA, 2009. Standards for Ruminant Feeding (in Polish). National Research Institute of Animal Production, Kraków

Khan M.A., Lee H.J., Lee W.S., Kim H.S., Kim S.B., Ki K.S., Park S.J., Ha J.K., Choi Y.J., 2007. Starch source evaluation in calf starter: I. Feed consumption body weight gain, structural growth, and blood metabolites in Holstein calves. J. Dairy Sci. 90, 5259-5268

Kotunia A., Woliński J., Laubitz D., Jurkowska M., Rome V., Guilloteau P., Zabielski R., 2004. Effect of sodium butyrate on the small intestine development in neonatal piglets feed by artificial sow. J. Physiol. Pharmacol. 55, Suppl. 2, 59-68

Lane M.A., Baldwin R.L. IV., Jesse B.W., 2000. Sheep rumen metabolic development in response to age and dietary treatments. J. Anim. Sci. 78, 1990-1996

Lane M.A., Baldwin R.L. IV., Jesse B.W., 2002. Development changes in ketogenic enzyme gene expression during sheep rumen development. J. Anim. Sci. 80, 1538-1544

Lane M.A., Jesse B.W., 1997. Effect of volatile fatty acid infusion on development of the rumen epithelium in neonatal sheep. J. Dairy Sci. 80, 740-746

McGavin M.D., Morrill J.L., 1976. Scanning electron microscopy of ruminal papillae in calves fed various amounts and forms of roughage. Amer. J. Vet. Res. 37, 497-508

Mentschel J., Leiser R., Mülling C., Pfarrer C., Claus R., 2001. Butyric acid stimulates rumen mucosa development in the calf mainly by a reduction of apoptosis. Arch. Tierenähr. 55, 85-102

Nocek J.E., Herbein J.H., Polan C.E., 1980. Influence of ration physical form, ruminal degradable nitrogen and age on rumen epithelial propionate and acetate transport and some enzymatic activities. J. Nutr. 110, 2355-2366

Quigley J.D. III., Bernard J.K., 1992. Effects of nutrient source and time of feeding on changes in blood metabolites in young calves. J. Anim. Sci. 70, 1543-1549

Quigley J.D. III., Wallis L.B., Dowlen H.H., Heitmann R.N., 1992. Sodium bicarbonate and yeast culture effects on ruminal fermentation, growth, and intake in dairy calves. J. Dairy Sci. 75, 3531-3538

SAS, 2002. Version 2.0, Sas Institute Inc. Cary, NC

SAS, 2001. Release 2.6 for Windows. SAS Institute Inc. Cary, NC

Stobo I.J.F., Roy J.H.B., Gaston H.J., 1966. Rumen development in the calf. 1. The effect of diets containing different proportions of concentrates to hay on rumen development. Brit. J. Nutr. $20,171-188$ 